\title{
Epidemiology of EHV-1 and EHV-4 infections: A review
}

\section{Saïd Derbal*}

Pharmaceutical Sciences Research Center, Ali Mendjli, Constantine, Algeria
Received: 29 August, 2021

Accepted: 21 September, 2021

Published: 22 September, 2021

*Corresponding author: Saïd Derbal, Pharmaceutical Sciences Research Center, Ali Mendjli, Constantine, Algeria, Tel: +213 773258207;

E-mail: saidderbal19@gmail.com

Keywords: EHV-1; EHV-4; Persistence; Spread; Respiratory disease; Abortion; Perinatal mortality; Neurological disease

Copyright: (c) 2021 Derbal S. This is an open-access article distributed under the terms of the Creative Commons Attribution License, which permits unrestricted use, distribution, and reproduction in any medium, provided the original author and source are credited.

https://www.peertechzpublications.com

Check for updates

\section{Abstract}

This review mainly focuses on the epidemiological characteristics of respiratory diseases, abortions, perinatal mortalities and neurological diseases in horses caused by EHV-1 and EHV-4. There are several sources of EHV-1 and EHV-4 which are transmitted by different routes. The latency and reactivation of EHV-1 and EHV-4 play an important role in the persistence of infection with these viruses in the equine population. These viruses are major agents in respiratory diseases in horses. Mares and their foals play an important role in the circulation of these viruses on farms. Abortion and perinatal mortality can take the sporadic or epizootic form. Neurological disease is caused primarily by neuropathogenic EHV-1. Combined epizootics of neurological diseases and abortions are common.

\section{Abbreviations}

EHV: Equine Herpesvirus; DNA: Deoxyribonucleic Acid; EIV: Equine Influenza Virus; IURD: Infectious Upper Respiratory Tract Disease; EMPF: Equine Multinodular Pulmonary Fibrosis; PCR: Polymerase Chain Reaction; SNP: Single Nucleotide Polymorphism; ORF: Open Reading Frame; EHM: Equine Herpesvirus Myeloencephalopathy

\section{Introduction}

The order Herpesvirales comprises three families since viruses infecting mammals, birds and reptiles are grouped together in the family Herpesviridae which is divided into three subfamilies, Alpha, Beta and Gammaherpesvirinae [1]. EHV-1 and EHV-4 are classified in the Alphaherpesvirinae subfamily, all belonging to the genus Varicellovirus [1,2]. Among equine herpesviruses, EHV-1 and EHV-4 are the most clinically, economically and epidemiologically relevant pathogens [3].

The herpesvirus is a linear double-stranded DNA virus with an icosahedral capsid surrounded by a structured integument and an envelope containing spikes of viral glycoproteins on the surface, and due to the varying size of the envelope, these viruses can range from 120 to $250 \mathrm{~nm}$ in diameter [4]. The identity between EHV-1 and EHV- 4 at the DNA level has been estimated to be 55 to $84 \%$ [5].

The animal can be clinically affected several times during its life and the resulting disease tends to be less severe [6]. Resistance to reinfection can be achieved after repeated infections [7]. EHV-1 and EHV-4 are very close antigenically since cross-reacting neutralizing antibodies can develop following multiple exposures to these viruses [5].

This review concerns EHV-1 and EHV-4 and mainly focuses on the persistence and spread of these viruses, and their epidemiology in sporadic and epizootic cases of respiratory disease, abortion, perinatal mortality and neurological disease.

\section{Persistence and spread of viruses}

Transmission of most EHVs between horses occurs directly as a result of direct exposure to exudates and aerosols and indirectly from air, water and environmental contaminants 
$[8,9]$. The most common route of transmission is the respiratory tract [5]. Infection can also occur by ingesting contaminated material through a runny nose [10]. Respiratory secretions from horses, foals, fetal and placental tissue, and aborted placental fluids are common sources of the virus $[10,11]$. Environmental factors have varying effects on the environmental persistence of EHV-1, which decreases over time and poses a risk of transmission [12]. EHV-1 can survive at room temperature on horsehair or burlap (35 days) and even on paper, wood or rope (one week) [13].

Horses and foals are contagious by the respiratory route in the active stage of the disease and probably during the later periods of viral reactivation and dissemination in latent infected horses because the latent period is unknown but is thought to be lifelong [6]. Most horses stop shedding the virus around 1 to 2 weeks after infection [14]. Nasal excretion after recrudescence of latent EHV-1 is short (2 days) [15]. EHV-1 can be excreted in the semen of infected stallions [16]. Transmission of EHV1 through semen has been suggested during mating or by artificial insemination [17]. EHV-1 and EHV-4 can be excreted in the nasal secretions of vaccinated mares and their unweaned and unvaccinated foals [18]. Usually, EHV-4 is excreted by male foals and foals with respiratory disease [19].

After infection, EHV-1 and EHV-4 localize in many neuronal and lymphoid tissues (lymphoreticular system, circulating CD8+ T cells, lymph nodes and trigeminal ganglion neurons) and become latent $[20,21]$. It is estimated that $>50 \%$ of the horse population is latent infected with EHV-1, and as a hypothesis, reactivation in latent infected horses is the major biological source of infectious virus [22]. Also, it is suggested that transmission of EHV-1 after reactivation of latent infection is due to stress of parturition, estrus activity or lactation [23]. Experimentally, EHV-1 can be reactivated by administration of high doses of glucocorticoids [24]. Clinical disease may result from this recrudescence [15]. In contrast, experimental reactivation of EHV-4 was performed with some difficulty and may not have mimicked natural reactivation [20]

Abortion or neurological disease can occur months or years after latent respiratory infection with EHV-1 [25]. Latency leads to the occurrence of sporadic cases of abortions and neurological diseases in horses reared in closed areas away from an external source of EHV-1 [26].

\section{Infections of foals and respiratory diseases}

EHV-1, EHV-4, Equine Influenza Virus (EIV) and Streptococcus equi subs. equi are the main pathogens responsible for Infectious Upper Respiratory Tract Disease (IURD) [27]. EHV-4 is the most common pathogen detected in horses showing clinical signs of IURD [27]. EHV-4 is usually isolated from foals with profuse serous or mucopurulent nasal discharge [19].

In Germany, an outbreak of EHV-4 respiratory disease affected 41 horses (20 foals, 10 stallions and 11 mares) and $73 \%$ of infected mares and their foals shed the virus at the same time. Several factors were involved in the onset of this outbreak such as stress caused by seasonal changes, management practices, routine equestrian activities and exercise [28]. Also, suppression of the ability to neutralize the virus in the nasal mucosa may occur after transport and may contribute to susceptibility to EHV-1 [29]. In China, a virological investigation of the agents causing an outbreak of respiratory disease showed the involvement of EHV-4 [30].

Seroepidemiological studies have demonstrated infection of 30-day-old foals with EHV-1 [31]. In addition, a seroepidemiological investigation showed positive results of EHV-1 and EHV-4 infection in vaccinated mares and their 5-week-old foals [18]. It was reported in another study that the seroprevalence of EHV-4 in all mares and foals tested was $99 \%$, and that of EHV-1 was $26.2 \%$ and $11.4 \%$ in mares and foals respectively [23].

The mare population is a source of virus for unweaned foals [23]. The mare and foal populations are considered to be a reservoir responsible for new infections in the foal population before and after weaning [31]. EHV-1 and EHV-4 can even circulate within the population of vaccinated mares and their unweaned foals [18]. Also in another study, it was reported that EHV -1 and EHV- 4 circulate widely in mare and foal populations but EVH- 4 was not the cause of the respiratory disease which affects all foals [32].

In addition, both gammaherpesviruses EHV-2 and EHV5 are classified in the group of less characterized respiratory viruses associated with IURD [33]. EHV-2 and EHV-5 have been detected in horses with mild respiratory disease [34], pneumonia [35] and multinodular pulmonary fibrosis (EMPF) $[36,37]$, and even in immunocompetent hosts, apparently healthy and without clinical signs of the disease [38,39]. Also, EHV-2 plays a role in the transactivation of EHV-1 and EHV-4 [40].

Several authors have reported co-infection with several EHVs in apparently healthy equines. In Korea, in a virological investigation of equine herpesviruses in clinically healthy horses, EHV-2 and EHV-5 were detected in $41.7 \%$ and $21.7 \%$ of blood samples, respectively, and in $13.4 \%$ and $18.7 \%$ of lung tissue, respectively. Also, EHV-1, EHV-2 and EHV-5 were detected in $12.0 \%, 5.5 \%$ and $11.2 \%$ of nasal swabs, respectively. Co-infection with EHV-2 and EHV-5 was detected in $11.6 \%$ of blood samples and $6.4 \%$ of lung tissue, and co-infection with EHV-1, EHV-2 and EHV- 5 was detected in $0.8 \%$ of nasal swabs [41]. In Egypt, a virological and serological investigation on four equine herpesviruses (EHV-1, EHV-2, EHV-4 and EHV-5) in different populations of Arabian horses and donkeys showed that these viruses are endemic and constitute a continuing threat to horses [42]. In China, study of the prevalence of EHV-2, EHV- 4 and EHV- 5 by virological analysis of 453 nasal swabs from clinically healthy foals $(36 / 453,7.9 \%)$ and horses (417/453, 92.1\%), showed that $9.9 \%$ of samples were positive for EHV-5 and $1.5 \%$ were positive for EHV-2, but all were negative for EHV-4 [30].

\section{Abortions and perinatal mortalities}

Abortion due to EHVs can take the form of sporadic events or disease outbreaks (epizootics) [43,44]. Abortions occur more 
frequently in the last three months of gestation and almost none before 4 months $[45,46]$. Also, perinatal mortality of foals can take the sporadic form or the form of epizootics [47]. Foals can be stillborn, alive but weak and die quickly or healthy at birth, become sick and die within 3 days of birth [47].

In a population of pregnant mares in Germany, the percentage of abortions reached $6.5 \%, 25 \%$ of these abortions were of infectious origin, of which $40 \%$ were due to EHV-1, or $10 \%$ of all abortions [48]. In France, fetoplacental infections represented $63.7 \%$ of abortion cases since, for infectious causes, the vast majority of abortion cases were caused by bacteria (79.9\%), followed by viruses (15.1\%) including EHV-1 and EHV-4, and fungi (1.8\%) [46]. In another study carried out in France, covering the period 2002-2005 and aimed to assess the contribution of five different EHVs to equine abortion using consensus PCR on 407 fetuses, stillborn foals, premature foals, EHV - 1 has been identified as the major cause of abortions in mares (59/407 cases, 14.5\%). Detection of EHV-2 and EHV-5 DNA in abortion cases has inferred a role for these viruses in abortion [49]. In UK, during an epizootic associated with EHV1, 11 of 18 unvaccinated mares (Welsh ponies) aborted [50].

In Hungary, out of 93 aborted equine fetuses and 8 weak foals, 15 (14.9\%) were found infected with EHV-1 by immunohistochemistry and $13(12.9 \%)$ by virological analysis [51]. In Great Britain, equine herpesvirus infections of fetuses or newborn foals were estimated at $6.5 \%$ of final diagnoses since $95 \%$ of these infections were caused by EHV -1 and $5 \%$ by EHV-4 [45]. In the Netherlands, out of 254 fetal and neonatal isolates, 244 (96\%) were typed as EHV-1 and 10 (4\%) as EHV-4 [52]. In Australia, 33 of 44 mares aborted or lost foals within the first day of birth, and 6 foals were infected with EHV-1 [43].

\section{Neuropathogenic strains and neurological diseases}

Recent research has increasingly focused on neuropathogenic (neurotropic or neurovirulent) strains of EHV-1. It was believed that these neuropathogenic and non-neuropathogenic strains could be distinguished via a single nucleotide polymorphism (SNP) in the ORF30 open reading frame of the gene encoding viral DNA polymerase with a single nucleotide substitution of adenine (A) at the guanine (G) at nucleotide 2254 causing the change from asparagine (N) to aspartic acid (D) at amino acid 752 [53]. Neurological disease appears to have a stronger association with the ORF30 $\mathrm{G}_{2254}$ genotype while the nonneuropathogenic biovariant (ORF30 $\mathrm{A}_{2254}$ genotype) has been linked primarily to non-neurological disease since 78 (95\%) of the non-neuropathogenic isolates encoded $\mathrm{A}_{2254}$ (acid amino $\mathrm{N}_{752}$ ), while $42(86 \%)$ of the neuropathogenic isolates encoded $\mathrm{G}_{2254}$ (amino acid $\mathrm{D}_{752}$ ) [53]. Currently, there are RT-PCR tests using allelic discrimination for detection and differentiation between these strains, neuropathogenic EHV-1 $\left(\mathrm{G}_{2254}\right)$ and non-neuropathogenic EHV-1 $\left(\mathrm{A}_{2254}\right)[54,55]$.

In Serbia, Bosnia and Herzegovina, 142 tissue and nasal swab samples from apparently healthy unvaccinated horses were examined and the results showed that the detection of EHV -1 by PCR and its isolation was in $81 \%$ and $45.1 \%$ of the analyzed samples, respectively, and $82.1 \%$ of the strains were neuropathogenic [56]. In South Korea, 12 EHV-1 isolates were isolated and characterized as non-neuropathogenic [57].

In central Kentucky, out of 426 archived EHV-1 isolates (1951-2006) collected from abortions, the percentage of isolates with a neuropathogenic genotype ranged from 3.3\% in the 1960 s to $14.4 \%$ in the 1990 s [58]. In Germany, for 32 EHV1 isolated from 06 abortion epizootics and 34 archived EHV-1 (1987-2009) isolated from sporadic cases, 89.4\% (59/66) of EHV-1 isolates from abortions were of non-neuropathogenic genotype $\left(\mathrm{A}_{2254} / \mathrm{N}_{752}\right)$ and $10.6 \%(7 / 66)$ were of neuropathogenic genotype $\left(\mathrm{G}_{2254} / \mathrm{D}_{752}\right)$ [59].

Epizootics of neurological diseases with simultaneous abortions have been reported. During a storm of abortions or perinatal deaths in Austria caused by EHV-1, 10 mares died with neurological disorders and 17 mares suffered from lameness and paralysis of varying degrees with 22 cases of abortion, stillbirths and premature foals [60]. Another combined epizootic of neurological diseases and abortions has occurred in Australia as out of 10 pregnant and lactating mares, 5 developed a neurological disease of which 3 died, one mare aborted and the other gave birth to an ataxic and incontinent foal [32]. In a neuropathogenic EHV-1 $\left(G_{2254} / D_{752}\right)$ epidemic affecting 61 horses in Germany, 8 horses developed EHM, 6 pregnant mares aborted of which 3 had EHM [61]. Also, in Brazil, EHV-1 was isolated from a fatal case of equine herpetic myeloencephalopathy in a mare and this strain is suggested to be neurovirulent [62].

There are factors that contribute to the onset of EHM since it has been reported that $24 \%$ of EHV-1 isolated from horses with neurological disease are strains containing the opposite allele (ORF30 $A_{2254}$ ) [63]. In Germany, during a severe abortion epizootic caused by EHV-1 (ORF30 $\left.\mathrm{G}_{2254}\right), 16$ pregnant mares vaccinated regularly with an inactivated vaccine aborted, two gave birth to weak non-viable foals and no neurological disease has been reported which suggests that vaccination of pregnant mares did not influence the occurrence of abortions but prevented the development of neurological diseases [44].

\section{Conclusion}

Due to the pathological importance of EHV-1 and EHV-4 in veterinary medicine, these viruses become an objective to be studied. These viruses are major pathogens that spread among susceptible horses during periods of latency and reactivation as they cause respiratory diseases, abortions, perinatal mortalities and neurological diseases. Latency and reactivation allow these viruses to persist and spread in the equine population. Infection with these viruses results in the appearance of different clinical forms of diseases either as sporadic cases or epizootics. There are epidemiological differences according to the concerned countries and the pathogenicity of the viral strains involved in the infection.

\section{References}

1. Davison AJ, Eberle R, Ehlers B, Hayward GS, McGeoch DJ, et al. (2009) The order Herpesvirales. Arch Virol 154: 171-177. Link: https://bit.ly/3AsS1RX 
2. Ma G, Azab W, Osterrieder N (2013) Equine herpesviruses type 1 (EHV-1) and 4 (EHV-4)-Masters of co-evolution and a constant threat to equids and beyond. Vet Microbiol 167: 123-134. Link: https://bit.ly/39rPOKV

3. Patel JR, Heldens J (2005) Equine herpesviruses 1 (EHV-1) and 4 (EHV-4) epidemiology, disease and immunoprophylaxis: A brief review. Vet $\mathrm{J} 170$ 14-23. Link: https://bit.ly/3IJ6nb1

4. James MacLachlan N, Dubovi EJ (2011) Herpesvirales. In: Fenner's veterinary virology, $4^{\text {th }}$ Edition, Elsevier, USA, 179-201. Link: https://bit.ly/3kog2US

5. O'Callaghan DJ, Osterrieder N (2008) Herpesviruses of Horses. In: Desk Encyclopedia of Animal and Bacterial Virology, $1^{\text {st }}$ Edition (Edited by Mahy B, van Regenmortel M), Elsevier, USA, 140-148

6. Constable PD, Hinchcliff KW, Done SH, Grünberg W (2017) Diseases of the Respiratory System. In: Veterinary Medicine: A Textbook of the Diseases of Cattle, Horses, Sheep, Pigs, and Goats, $11^{\text {th }}$ Edition, Elsevier, USA, 845-1090.

7. Reed SM, Toribio RE (2004) Equine herpesvirus 1 and 4. Vet Clin North Am Equine Pract 20: 631-642. Link: https://bit.ly/3IIGNTh

8. Hussey GS, Landolt GA (2015) Equine Alphaherpesviruses. In: Robinson's Current Therapy in Equine Medicine, $7^{\text {th }}$ Edition (Edited by Sprayberry KA, Robinson NE), Elsevier, USA, 158-161.

9. Dayaram A, Seeber PA, Greenwood AD (2021) Environmental detection and potential transmission of equine herpesviruses. Pathogens 10: 423. Link: https://bit.ly/3zwR1eq

10. Lunn DP, Davis-Poynter N, Flaminio MJBF, Horohov DW, Osterrieder K, et al (2009) Equine herpesvirus-1 consensus statement. J Vet Intern Med 23: 450 461. Link: https://bit.ly/3hUrN3P

11. Gardiner DW, Lunn DP, Goehring LS, Chiang YW, Cook C, et al. (2012) Strain impact on equine herpesvirus type 1 (EHV-1) abortion models: Viral loads in fetal and placental tissues and foals. Vaccine 30: 6564-6572. Link: https://bit.ly/3EGb11S

12. Saklou NT, Burgess BA, Ashton LV, Morley PS, Goehring LS (2021) Environmental persistence of equid herpesvirus type-1. Equine Vet J 53: 349355. Link: https://bit.ly/3IIGNTs

13. Doll ER, McCollum WH, Bryans JT, Crowe ME (1959) Effect of physical and chemical environment on the viability of equine rhinopneumonitis virus propagated in hamsters. Cornell Vet 49: 75-81. Link: https://bit.ly/3CA8Rir

14. Gibson JS, Slater JD, Field HJ (1992b) The pathogenicity of Ab4p, the sequenced strain of equine herpesvirus-1, in specific pathogen-free foals. Virology 189: 317-319. Link: https://bit.ly/3koX1lg

15. Gibson JS, Slater JD, Awan AR, Field HJ (1992a) Pathogenesis of equine herpesvirus-1 in specific pathogen-free foals: Primary and secondary infections and reactivation. Arch Virol 123: 351-366. Link: https://bit.ly/2XFbml4

16. Walter J, Balzer HJ, Seeh C, Fey K, Bleul U, et al. (2012) Venereal shedding of equid herpesvirus-1 (EHV-1) in naturally infected stallions. J Vet Intern Med 26 1500-1504. Link: https://bit.ly/3nSCpnF

17. Hebia-Fellah I, Léauté A, Fiéni F, Zientara S, Imbert-Marcille BM, et al. (2009) Evaluation of the presence of equine viral herpesvirus 1 (EHV-1) and equine viral herpesvirus 4 (EHV-4) DNA in stallion semen using polymerase chain reaction (PCR). Theriogenology 71: 1381-1389. Link: https://bit.ly/3CwYagN

18. Foote CE, Love DN, Gilkerson JR, Wellington JE, Whalley JM (2006) EHV1 and EHV-4 infection in vaccinated mares and their foals. Vet Immunol Immunopathol 111: 41-46. Link: https://bit.ly/3IIHBaL

19. Gilkerson JR, Jorm LR, Love DN, Lawrence GL, Whalley JM (1994) Epidemiological investigation of equid herpesvirus-4 (EHV-4) excretion assessed by nasal swabs taken from thoroughbred foals. Vet Microbiol 39 : 275-283. Link: https://bit.ly/3tVKb0Z
20. Crabb BS, Studdert MJ (1995) Equine herpesvirus 4 (equine rhinopneumonitis virus) and 1 (equine abortion virus). Adv Virus Res 45: 153-190. Link: https://bit.ly/3tXU8L8

21. Samoilowa S, Giessler KS, Torres CEM, Hussey GS, Allum A, et al. (2021) Equid herpesvirus- 1 distribution in equine lymphoid and neural tissues 70 days post infection. Pathogens 10: 707. Link: https://bit.ly/39qJPpu

22. Brown JA, Mapes S, Ball BA, Hodder AD, Liu IK, et al. (2007) Prevalence of equine herpesvirus- 1 infection among thoroughbreds residing on a farm on which the virus was endemic. J Am Vet Med Assoc 231: 577-580. Link: https://bit.ly/3nPv6gt

23. Gilkerson JR, Whalley JM, Drummer HE, Studdert MJ, Love DN (1999b) Epidemiology of EHV-1 and EHV-4 in the mare and foal populations on a Hunter Valley stud farm: Are mares the source of EHV-1 for unweaned foals. Vet Microbiol 68: 27-34. Link: https://bit.ly/2Z60vir

24. Edington N, Bridges CG, Huckle A (1985) Experimental reactivation of equid herpesvirus 1 (EHV 1) following the administration of corticosteroids. Equine Vet J 17: 369-372. Link: https://bit.ly/2VYqCbH

25. Allen GP (2006) Antemortem detection of latent infection with neuropathogenic strains of equine herpesvirus-1 in horses. Am J Vet Res 67: 1401-1405. Link: https://bit.ly/3kqbey5

26. Crowhurst FA, Dickinson G, Burrows R (1981) An outbreak of paresis in mares and geldings associated with equid herpesvirus 1. Vet Rec 109: 527-528. Link: https://bit.ly/3tVPduc

27. Pusterla N, Kass PH, Mapes S, Johnson C, Barnett DC, et al. (2011) Surveillance programme for important equine infectious respiratory pathogens in the USA. Vet Rec 169: 12. Link: https://bit.ly/39mf70z

28. Pavulraj S, Eschke K, Theisen J, Westhoff S, Reimers G, et al. (2021) Equine herpesvirus type 4 (EHV-4) outbreak in Germany: virological, serological, and molecular investigations. Pathogens 10: 810. Link: https://bit.ly/2W20Ljg

29. Bannai H, Takahashi Y, Ohmura H, Ebisuda Y, Mukai K, et al. (2021) Decreased virus-neutralizing antibodies against equine herpesvirus type 1 in nasa secretions of horses after 12-hour transportation. J Equine Vet Sci 103 103665. Link: https://bit.ly/2XMJM5

30. Xie J, Tong P, Zhang L, Ren M, Song X, et al. (2021) First detection and genetic characterization of equid herpesvirus 2,4 , and 5 in China. Arch Virol 166 1421-1426. Link: https://bit.ly/3ECW6FT

31. Gilkerson JR, Whalley JM, Drummer HE, Studdert MJ, Love DN (1999a) Epidemiological studies of equine herpesvirus 1 (EHV-1) in Thoroughbred foals: A review of studies conducted in the Hunter Valley of New South Wales between 1995 and 1997. Vet Microbiol 68: 15-25. Link: https://bit.ly/3Cvrq7B

32. Studdert M, Hartley C, Dynon K, Sandy J, Slocombe R, et al. (2003) Outbreak of equine herpesvirus type 1 myeloencephalitis: New insights from virus identification by PCR and the application of an EHV-1 -specific antibody detection ELISA. Vet Rec 153: 417-423.

33. Pusterla N, Mapes S, Wademan C, White A, Hodzic E (2013) Investigation of the role of lesser characterised respiratory viruses associated with upper respiratory tract infections in horses. Vet Rec 172: 315-317. Link: https://bit.ly/3IJ80ub

34. Dynon K, Black WD, Ficorilli N, Hartley CA, Studdert MJ (2007) Detection of viruses in nasal swab samples from horses with acute, febrile, respiratory disease using virus isolation, polymerase chain reaction and serology. Aust Vet J 85: 46-50. Link: https://bit.ly/3CBsJIB

35. Dunowska M, Howe L, Hanlon D, Stevenson M (2011) Kinetics of equid herpesvirus type 2 infections in a group of Thoroughbred foals. Vet Microbio 152: 176-180. Link: https://bit.ly/2Xyi5Nh

36. Soare T, Leeming G, Morgan R, Papoula-Pereira R, Kipar A, et al. (2011) Equine multinodular pulmonary fibrosis in horses in the UK. Vet Rec 169: 313-313. Link: https://bit.ly/3IJ8WtF 
37. Back H, Kendall A, Grandon R, Ullman K, Treiberg-Berndtsson L, et al. (2012) Equine multinodular pulmonary fibrosis in association with asinine herpesvirus type 5 and equine herpesvirus type 5: a case report. Acta Vet Scand 54: 57 Link: https://bit.ly/3Astl6Y

38. Torfason EG, Thorsteinsdottir L, Torsteinsdottir S, Svansson V (2008) Study of equid herpesviruses 2 and 5 in Iceland with a type-specific polymerase chain reaction. Res Vet Sci 85: 605-611. Link: https://bit.ly/3CxQHOV

39. Marenzoni ML, Coppola G, Maranesi M, Passamonti F, Cappelli K, et al. (2010) Age-dependent prevalence of equid herpesvirus 5 infection. Vet Res Comm 34: 703-708. Link: https://bit.ly/3EBLnvo

40. Welch HM, Bridges CG, Lyon AM, Griffiths L, Edington N (1992) Latent equid herpesviruses 1 and 4 : detection and distinction using the polymerase chain reaction and co-cultivation from lymphoid tissues. J Gen Virol 73: 261-268. Link: https://bit.ly/3IK3Kpd

41. Seo MG, Ouh IO, Lee SK, Lee JS, Kwon OD, et al. (2020) Molecular detection and genetic characteristics of equine herpesvirus in Korea. Pathogens 9: 110 Link: https://bit.ly/3kqLaD2

42. Azab W, Bedair S, Abdelgawad A, Eschke K, Farag GK, et al. (2019) Detection of equid herpesviruses among different Arabian horse populations in Egypt. Vet Med Sci 5: 361-371. Link: https://bit.ly/3IPYrou

43. Carrigan M, Cosgrove $P$, Kirkland $P$, Sabine $M$ (1991) An outbreak of equid herpesvirus abortion in New South Wales. Equine Vet $\mathrm{J}$ 23: 108-110. Link: https://bit.ly/3o0wxZg

44. Damiani AM, De Vries M, Reimers G, Winkler S, Osterrieder N (2014) A severe equine herpesvirus type 1 (EHV-1) abortion outbreak caused by a neuropathogenic strain at a breeding farm in northern Germany. Vet Microbiol 172: 555-562. Link: https://bit.ly/3CxYfAY

45. Smith K, Blunden A, Whitwell K, Dunn K, Wales A (2003) A survey of equine abortion, stillbirth and neonatal death in the UK from 1988 to 1997. Equine Vet J 35: 496-501. Link: https://bit.ly/2XKhh8m

46. Laugier C, Foucher N, Sevin C, Leon A, Tapprest J (2011) A 24-year retrospective study of equine abortion in Normandy (France). Journal of Equine Veterinary Science 31: 116-123. Link: https://bit.ly/3IMPMmn

47. Hartley WJ, Dixon RJ (1979) An outbreak of foal perinatal mortality due to equid herpesvirus type I: pathological observations. Equine Vet J 11: 215-218 Link: https://bit.ly/3hRGtRh

48. Van Maanen C, Willink D, Smeenk L, Brinkhof J, Terpstra C (2000b) An equine herpesvirus 1 (EHV1) abortion storm at a riding school. Vet Q 22: 83-87. Link: https://bit.ly/3EzOzHQ

49. Léon A, Fortier G, Fortier C, Freymuth F, Tapprest J, et al. (2008) Detection of equine herpesviruses in aborted foetuses by consensus PCR. Vet Microbiol 126: 20-29. Link: https://bit.ly/3zsxZG0

50. Irwin V, Traub-Dargatz J, Newton J, Scase T, Davis-Poynter N, et al. (2007) Investigation and management of an outbreak of abortion related to equine herpesvirus type 1 in unvaccinated ponies. Vet Rec 160: 378-380. Link: https://bit.ly/3ks2uYz

51. Szeredi L, Pálfi V, Molnár T (2003) Comparison of methods for the diagnosis of equine herpesvirus type 1 infection. Acta Vet Hung 51: 153-163. Link https://bit.ly/3IMxyS6

52. van Maanen C, Vreeswijk J, Moonen P, Brinkhof J, De Boer-Luijtze E, et al (2000a) Differentiation and genomic and antigenic variation among fetal, respiratory, and neurological isolates from EHV1 and EHV4 infections in the Netherlands. Vet Q 22: 88-93. Link: https://bit.ly/3nQz1tp

53. Nugent J, Birch-Machin I, Smith K, Mumford J, Swann Z, et al. (2006) Analysis of equid herpesvirus 1 strain variation reveals a point mutation of the DNA polymerase strongly associated with neuropathogenic versus nonneuropathogenic disease outbreaks. J Virol 80: 4047-4060. Link: https://bit.ly/3AsZCQN
54. Allen GP, Bolin DC, Bryant U, Carter C, Giles R, et al. (2008) Prevalence of latent, neuropathogenic equine herpesvirus- 1 in the thoroughbred broodmare population of central Kentucky. Equine Vet J 40: 105-110. Link: https://bit.ly/39rSMPz

55. Smith KL, Li Y, Breheny P, Cook RF, Henney PJ, et al. (2012) New real-time PCR assay using allelic discrimination for detection and differentiation of equine herpesvirus-1 strains with A2254 and G2254 polymorphisms. J Clin Microbio 50: 1981-1988. Link: https://bit.ly/3nTzICm

56. Radalj A, Milić N, Stevanović O, Veljović L, Nišavić J (2021) Genetic characterization of equine herpesvirus 1 from clinical cases and asymptomatic horses in Serbia and Bosnia and Herzegovina. Pak Vet $\mathrm{J} 7$

57. Kang HW, Lee EY, Lee KK, Ko MK, Park JY, et al. (2021) Evaluation of the Variability of the ORF34, ORF68, and MLST Genes in EHV-1 from South Korea. Pathogens 10: 425. Link: https://bit.ly/3zqblbN

58. Smith KL, Allen GP, Branscum AJ, Frank Cook R, Vickers ML, et al. (2010) The increased prevalence of neuropathogenic strains of EHV-1 in equine abortions. Vet Microbiol 141: 5-11. Link: https://bit.ly/3nUj5Gj

59. Fritsche AK, Borchers K (2011) Detection of neuropathogenic strains of equid herpesvirus 1 (EHV-1) associated with abortions in Germany. Vet Microbiol 147: 176-180. Link: https://bit.ly/3CCzle5

60. Chowdhury SI, Kubin G, Ludwig H (1986) Equine herpesvirus type 1 (EHV 1) induced abortions and paralysis in a Lipizzaner stud: A contribution to the classification of equine herpesviruses. Arch Virol 90: 273-288. Link: https://bit.ly/3ztBrA4

61. Walter J, Seeh C, Fey K, Bleul U, Osterrieder N (2013) Clinical observations and management of a severe equine herpesvirus type 1 outbreak with abortion and encephalomyelitis. Acta Vet Scand 55: 19. Link: https://bit.ly/3ECZosx

62. Lara MCCSH, Cunha EMS, Villalobos EMC, Nassar AFC, Asano KM, et al. (2008) First isolation of equine herpesvirus type 1 from a horse with neurological disease in Brazil. Arq Inst Biol 75: 221-224. Link: https://bit.ly/3CtJT4v

63. Perkins GA, Goodman LB, Tsujimura K, Van de Walle GR, Kim SG, et al. (2009) Investigation of the prevalence of neurologic equine herpes virus type 1 (EHV1) in a 23-year retrospective analysis (1984-2007). Vet Microbiol 139: 375378. Link: https://bit.ly/3hSFPTD

Discover a bigger Impact and Visibility of your article publication with

Peertechz Publications

\section{Highlights}

* Signatory publisher of ORCID

* Signatory Publisher of DORA (San Francisco Declaration on Research Assessment)

* Articles archived in worlds' renowned service providers such as Portico, CNKI, AGRIS, TDNet, Base (Bielefeld University Library), CrossRef, Scilit, J-Gate etc.

- Journals indexed in ICMJE, SHERPA/ROMEO, Google Scholar etc.

* OAI-PMH (Open Archives Initiative Protocol for Metadata Harvesting)

* Dedicated Editorial Board for every journa

* Accurate and rapid peer-review proces

* Increased citations of published articles through promotions

- Reduced timeline for article publication

Submit your articles and experience a new surge in publication services (https://www.peertechz.com/submission). 